\title{
JOURNAL.RU
}

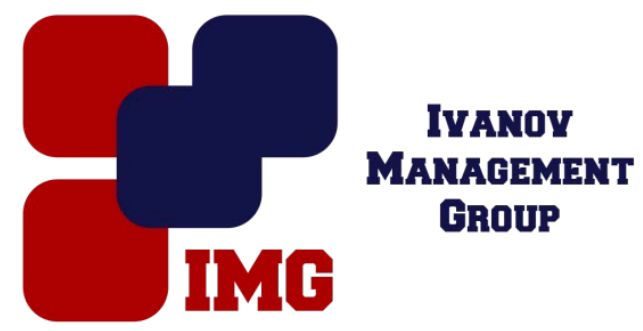

Горбунова Н.В., Евтеев А.В., Киселева И.С., Банникова А.В. Саратовский государственный аграрный университет им. Н.И. Вавилова

Саратов, Россия

doi: 10.18411/lj-31-01-2017-4-02

idsp 000001:lj-31-01-2017-4-02

\section{Изучение влияния антиоксидантов на технологические свойства пищевых продуктов}

\section{Аннотация}

Представлены результаты изучения воздействия антиоксидантов на внешний вид продукта, а также на сроки хранения полуфабрикатов из мяса индейки. В результате было установлено оптимальное количество ликопина позволяющего продлить сроки хранения.

Ключевые слова: антиоксиданты, органолептический анализ, срок хранения, дефицит эссенциальных веществ.

Проблема дефицита эссенциальных веществ в питании населения нашей страны является одной важнейших проблем. В 2013 году было принято постановление «О мерах по профилактике заболеваний, обусловленных дефицитом микронутриентов, развитию производства пищевых продуктов функционального и специализированного назначения». В рамках, которого основное внимание было обращено на концепцию обеспечения санитарноэпидемиологического благополучия населения, по средствам развития производств направленных на изготовление функциональных пищевых продуктов [1, 3].

Вместе с тем, юридическим лицам и индивидуальным предпринимателям, настоятельно рекомендовано расширять ассортимент продуктов функциональной направленности, обогащенных ценными компонентами, такими как пищевые волокна, витамины, минералы, антиоксиданты, полноценные белки. В частности, с целью снижения дефицита йода в организме человека было предложено обогащать продукты массового спроса йодированной солью $[2,3]$.

Медицинские исследования, проведенные в России показали недостаток таких эссенциальных компонентов, как витамины С, В1, В2, В6, фолиевая кислота, бета-каротин, ликопин, минеральные вещества (кальций, натрий, 
калий), микроэлементы (йод, фтор, селен, цинк, железо), пищевые волокна и полиненасыщенные жирные кислоты.

Среди каротиноидов ликопин выделяется высокой антиокислительной активностью и отсутствием токсического действия, даже в высоких дозах. По сравнению с бета-каротином, он способен нейтрализовать значительно большее количество синглетного кислорода. Ликопин концентрируется в клеточных мембранах, защищая их от повреждающего действия активных форм кислорода и окиси азота. Ликопин защищает лимфоциты от NO2. Несмотря на то, что целебные свойства ликопина определяются, в основном, его антиоксидантным действием, накапливающиеся данные свидетельствуют о возможной вовлечённости других механизмов, таких как модуляция межклеточных взаимодействий, воздействие на эндокринную и иммунную системы и пути метаболизма [8].

Ликопин является одним из наиболее мощных антиоксидантов, он умешает реакционную способность активного кислорода в два раза выше, чем у бета-каротина и в 10 раз выше, чем у $\alpha$ - токоферола. Ликопин является наиболее преобладающим каротиноидом в плазме крови человека, уровень зависит от нескольких биологических факторов и образа жизни. Вследствие их липофильной природы, они встречаются в концентрированной форме сыворотки. В организме ликопин концентрируется в надпочечниках, яичках, печени и предстательной железы. Специфическое распределение ликопина может иметь большое значение в роли воздействия этого антиоксиданта на организм человека $[4,5,6]$.

Целью данного исследования стало изучение влияния антиоксидантов на окрашивание фаршевых систем, а также на сроки хранения готовых полуфабрикатов из мяса индейки. Оценка цвета фарша была проведена на колориметре Minolta (CR-100, Япония). Различные цветовые гаммы представлены в шкалах $\mathrm{L}^{*},+\mathrm{a}^{*}, \mathrm{a}^{*},+\mathrm{b}^{*}, \mathrm{~b}^{*}$, представляющих степень белого, красного, зеленого, желтого и синего цветов, соответственно [7]. Общая микробиологическая обсеменённость фаршевых систем была проведена по известным методикам.

Для оценки окрашивающего эффекта фаршей были подготовлены 5 образцов с включением ликопина в количестве от 4,5 до 8,5 мг. Результаты исследования представлены в таблице 1 и на рисунке 1.

Таблищза 1

Влияние ликопина на цุветность фарша

\begin{tabular}{|c|c|c|c|c|c|}
\hline \multirow{2}{*}{ Параметры } & \multicolumn{5}{|c|}{ Количество ликопина, мг } \\
\cline { 2 - 6 } & 4,5 & 5,5 & 6,5 & 7,5 & 8,5 \\
\hline $\mathrm{L}^{*}$ & 56.13 & 53.86 & 54.55 & 48.31 & 49.22 \\
\hline $\mathrm{a}^{*}$ & 12.62 & 17.72 & 23,05 & 32.29 & 33.17 \\
\hline $\mathrm{b}^{*}$ & 10.99 & 12.85 & 16,88 & 23.12 & 26.72 \\
\hline
\end{tabular}

$n=3 ; L^{*}=$ ось белизны (0 черный, 100 бельй); $a^{*}=$ красный - зеленый ("+" значения красного, "-" значения зеленого, 0 является нейтральным); $b$ * = синий - желтый ("+" желтый, "-" синий, 0 является нейтральным) 
В результате исследования можно сделать вывод о том, что фарш с включением ликопина в количестве $\leq 6,5$ мг имеет бледный оттенок красного, а при использовании $\geq 6,5$ мг ликопина фарш приобретает интенсивный цвет, что может показаться потребителю ненатуральным. Таким образом, наиболее привлекательный цвет фарша получается при использовании 6,5 мг ликопина.

Были произведены измерения уровня $\mathrm{pH}$ для всех образцов фаршевых систем, данные исследования представлены в таблице 2. Уровень рН для всех образцов находился в пределах нормы, однако он увеличивался с течением времени. Согласно Рекомендации по уровню потребления пищевых и биологически активных веществ, следует употреблять порядка 5 мг ликопина в сутки, верхний допустимый уровень потребления 10 мг в сутки. В этой связи, для оценки увеличения сроков хранения мясных полуфабрикатов были проведены микробиологические исследования на фарше, приготовленного по рецептуре № 3. Результаты исследований представлены в таблице 3.

Таблий 2

Изменение уровня рН в зависимости от количества использованного ликопина

\begin{tabular}{|c|c|c|c|c|}
\hline \multirow{2}{*}{ Количество ликопина, мг } & \multicolumn{4}{|c|}{$\mathrm{pH}$} \\
\cline { 2 - 5 } & На 2-е сутки & На 6-е сутки & На 10 сутки & На 12 сутки \\
\hline 4,5 & 6,11 & 6,23 & 6,5 & 6,9 \\
\hline 5,5 & 6,15 & 6,27 & 6,61 & 6,92 \\
\hline 6,5 & 6,08 & 6,13 & 6,45 & 6,87 \\
\hline 7,5 & 6,08 & 6,12 & 6,48 & 6,86 \\
\hline 8,5 & 6,11 & 6,18 & 6,57 & 6,94 \\
\hline \multicolumn{4}{|c}{ Таблича 3 }
\end{tabular}

\begin{tabular}{|c|c|c|c|c|c|c|}
\hline & & икробиологи & ие пока & ели фарша & & \\
\hline \multirow[b]{2}{*}{ Образец } & \multirow{2}{*}{$\begin{array}{l}\text { МАФАнМ } \\
\text { КОЕ/г, не } \\
\text { более }\end{array}$} & \multicolumn{4}{|c|}{ Масса продукта (г), в которой не допускается наличие } & \multirow{2}{*}{$\begin{array}{c}\text { Дрожжи и } \\
\text { плесени } \\
\text { мг/кг, не } \\
\text { более }\end{array}$} \\
\hline & & $\begin{array}{c}\text { БГКП } \\
\text { (колиформы) }\end{array}$ & S.aureus & Сальмонеллы & Proteus & \\
\hline $\begin{array}{c}\text { По } \\
\text { тех.регламенту }\end{array}$ & $5 \times 10^{3}$ & 0 & 0 & 0 & 0 & 500 \\
\hline На 2-е сутки & $1,2 \times 10^{3}$ & 0 & 0 & 0 & 0 & 0 \\
\hline На 6-е сутки & $2,5 \times 10^{3}$ & 0 & 0 & 0 & 0 & 0 \\
\hline На 12-е сутки & $4,1 \times 10^{3}$ & 0 & 0 & 0 & 0 & 0 \\
\hline
\end{tabular}

В результате микробиологических исследований показано, что ликопин положительно влияет на сроки хранения, продлевая их на несколько дней. Также в результате исследований были выявленные основные параметры цвета фарша и его окрашивания при помощи ликопина. Таким образом, рекомендуемое количество включения ликопина в фарш составляет 6,5 мг, что составляет $63 \%$ от рекомендованной суточной нормы.

В рамках данного исследования было доказано положительное влияние ликопина на технологические свойства продукта и сроки хранения готового полуфабриката из мяса индейки, что является актуальным в области установления антиоксидантного влияния эссенциальных компонентов на продукты питания. 


\section{Литература}

1. Горбунова, Н.В., Евтеев, А.В., Банникова, А.В. Изменение механических свойств инкапсулированных форм аскорбиновой кислоты в условиях ферментативного гидролиза in vitro. Материалы Международной научно-практической конференции «Современное состояние, перспективы развития молочного животноводства и переработки сельскохозяйственной продукции», 7-8 апреля 2016 г., г. Омск. - с. 222225.

2. Банникова, А.В. Разработка технологии инкапсулированных форм белков и антиоксидантов. Современная наука и инновации. - 2016. - №1 (16). - С. 56-60.

3. О мерах по профилактике заболеваний, обусловленных дефицитом микронутриентов, развитию производства пищевых продуктов функционального и специализированного назначения: Постановление главного санитарного врача Российской Федераций от 14.06.2013 № 31

4. Astorg P, Gradelet S, Berges R, Suschetet M. Dietary lycopene decreases the initiation of liver preneoplastic foci by diethylnitrosamine in the rat. Nutr Cancer 1997;29(1):608.[PubMed]

5. Jain CK, Agarwal S, Rao AV. The effect of dietary lycopene on bioavailability, tissue distribution, in-vivo antioxidant properties and colonic preneoplasia in rats. Nutr Res 1999;19:1383-91.

6. Levy J, Bosin E, Feldmen B, Giat Y, Miinster A, Danilenko M, et al. Lycopene is a more potent inhibitor of human cancer cell proliferation than either $\alpha$-carotene or $\beta$-carotene. Nutr Cancer1995;24:257-66. [PubMed]

7. Nagasawa H, Mitamura T, Sakamoto S, Yamamoto K. Effects of lycopene on spontaneous mammary tumour development in SHN virgin mice. Anticancer Res 1995;15:1173-8. [PubMed]

8. Jafarpour, A., Sherkat, F., Leonard, B. \& Gorczyca, E.M. Colour improvement of common carp (Cyprinus carpio) fillets by hydrogen peroxide for surimi production / A. Jafarpour, F. Sherkat, B. Leonard \& E.M. Gorczyca // International Journal of Food Science and Technology. - 2008. - 43. - pp. 1602- 1609. 